ついで 30 分間加熱還流させた。反応液を口過し，ケーキを $10 \mathrm{~m} l$ のベンゼンで洗浄した。洗液の一部をとりガスクロマトグラ ム*5 で調べると, ジェチルジスルフィド[4]のピークを示す。ピ ーク高さから〔4]は $1.95 \mathrm{~g}$ であった。収率 $86.6 \%$ 。

\section{3 ジフェニルスルフィド[5]と過酸化ニッケルとの反応}

〔5]の $3.72 \mathrm{~g}$ をベンゼン $30 \mathrm{ml}$ に溶かし過酸化ニッケル $(f$ =0.0493)18.5.g を加え，10 時間ベンゼンの洲点でかきまぜた。 反応液を口過し，ケーキをベンゼンで洗浄した。ケーキを希硫酸 で処理してニッケル化合物を溶かすと不溶物が残った。これをエ 一テルで抽出し, 溶媒を留去すると $1.37 \mathrm{~g}$ のシフェニルスルホ ン〔6]を得た。 $\mathrm{mp} 125 \sim 126^{\circ} \mathrm{C} * 6$ (エタノールから再結晶)。赤 外吸収： $1150 \mathrm{~cm}^{-1}$ (スルホン)。

分析値 C $66.15 \%, \mathrm{H} 4.79 \%, \mathrm{~S} 14.66 \%, \mathrm{O} 14.57 \%$

*5 装置: F6D (日立-Parkin Elmer), カラム: DG 550-PEG $20 \mathrm{M}(5: 2) 20 \%$ on C-P (100/120)SUS $3 \mathrm{~mm} \phi \times 1 \mathrm{~m}$, 力

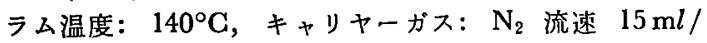
$\min$, サンプル: 口洗夜そのまま $1 \mu l, t_{\mathrm{R}}: 6.0 \mathrm{~min}$, 定 量: 絶対定量法.

*6 文献值 $125^{\circ} \mathrm{C}(\mathrm{F}$. Mauthner, Ber., 39, 3594(1906)).

\section{$\mathrm{C}_{12} \mathrm{H}_{10} \mathrm{SO}_{2}$ としての}

計算值 C $66.03 \% ， \mathrm{H} 4.62 \% ， \mathrm{~S} 14.69 \% ， \mathrm{O} 14.69 \%$ 一方, 反応液の口洗液を合わせて蒸発嗼固し, アメようの残留 物を石油エーテルで抽仙すると不溶物として $0.7 \mathrm{~g}$ の結晶を得 た。エタノールから再絬晶すると $\mathrm{mp} 125 \sim 126^{\circ} \mathrm{C}$ 。さきの 6 。 と混融の結果, ジフェニルスルホンであった。合計収量 $2.07 \mathrm{~g} 。$ 収量 $47.5 \%$ 。

石油エーテル抽出液を蒸発すると $1.3 \mathrm{~g}$ の bp 290 ～ $295^{\circ} \mathrm{C}$ の 油状物を得た。赤外吸収スペクトルの一致から原料 5 】であるこ とを確認した。回収率 $35 \%$ 。

3.4 ジフェニレンスルフィド[7]と過酸化ニッケルとの反応

〔7]0 $3.7 \mathrm{~g}$ 芯ベンゼン $30 \mathrm{ml}$ に溶かし過酸化ニッケル $(f=$ 0.0406) $23.6 \mathrm{~g}$ を加え，かきまぜながら 10 時間加熱還流した。反 応液を口過し，ケ一キをベンゼンで洗浄した。洗液を合わせて 蒸発し $3.51 \mathrm{~g}$ の結晶を得た。一方,ケーキを希硫酸で処理し, 二 ッヶル化合物を溶解し $0.1 \mathrm{~g}$ の結晶を得た。雨結晶ともに〔7〕と 混融して降下せず，未反応物〔7〕の回収であった。回収染 $98 \%$ 。

終りに，本研究において種々ご指導をしていただいた大阪大学 理学部村橋俊介教授に厚く感謝します。

\title{
$\boldsymbol{\alpha}$-アミノ酸を用いた光学活性樹脂の合成およびその不整吸着現象
}

(昭和 42 年 7 月 28 日受理)

上村多嘉彦·山下 徹 志 -中 村 暢 夫*1

1952 年 Bunnett と Marks' ${ }^{1)}$ が光学活性樹脂を合成し，これを 用いて有機ラ七う体の光学分割を試みて以来，かなりの数のこの 系統の仕事が発表されてきた。そしてその方法は二つに大別され る。その一つは既製のポリマー基体，たとえばポリクロルメチル スチレン22 4), カルボン酸型イオン交換樹脂5)などと光学活性体 とを反応させ，光学活性樹脂をうるものであるが，これらは不均 一系反応を用いるため性質が必ずしも均一でなく再現性にそし いか。また再使用のための賦活に適さず，このため分割データの 再検討にも不適である。また他の一つは L-チロシンなどから䆃 かれるフェノール性樹脂1)6であるが，フェノール性樹脂は一般 に硬い塊状で得られ，これを均一な粒子にそろえるのむむずかし い。また緩和な重合条件であるとはいえずラセミ化のおとれがな

*1 Takahiko Uemura, Tetsushi Yamashita, Nobuo NakaMURA 大阪市立大学理学部化学教室, 大阪市住吉区杉本 町

1) J. F. Bunnett, J. L. Marks, J. Am. Chem. Soc., 74, 5893(1952).

2) S. Tsuboyama, M. Yanagita, Sci. Papers. Inst. Phys. Chem. Res. (Tokyo), 53, 245(1959).

3) H. Suda, R. Oda，金沢大学工学部紀要, 2, 215(1960); Chem. Abst., 55, 23305(1961).

4) J. A. Lott, W. Riemann, J. Org. Chem., 31, 561 (1966).

5) N. Grubrofer, L. Schleith, Z. Physiol. Chem., 296, 262(1954).

6) G. Losse, H. Jeschkect, G. Fückert, H. Rabe, $Z$. Naturforsch., 176, 419(1962).
いとはいえない。これらは既報の分割結果がいずれも微小である ことを考えるとかなり大きな欠点と思われる。これらのことから 光学活性なスチレンあるいはアクリル系モノマーを合成し，これ を比較的緩和な 条件下で重合し，こうして得た樹脂の不整吸着 現象について 検討することは意義があると考えられる。さきに Robertら》が $p$-クロルメチルスチレンとL-シスチンからモノマ 一を合成し，この重合を試みたが不成功に終り，ふたたびポりク ロルメチルスチレンから出発する方法にもどっている。著者らは

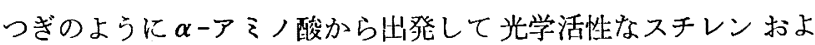
びアクリル系モノマーを合成し，これを架橋郕とともに溶液中重 合し, 比較的量産可能で有機溶媒, 希酸およびアルカリに不溶, かつ安定で性質が一定した均一な粒子の樹脂を得た。まず L-ア ミノ酸を氷冷水酸化ナトリウム中，アクリル酸クロリドと反応さ せて，つぎのような酸性アクリルモノマーを得た。

\section{$\mathrm{R}-\mathrm{CH}-\mathrm{COOH}^{8}$} NंHCOCH$=\mathrm{CH}_{2}$

$$
\begin{aligned}
& \mathrm{R}=-\mathrm{CH}_{\backslash \mathrm{CH}_{3}}^{\mathrm{CH}_{3}}, \mathrm{mp} 119^{\circ} \mathrm{C},[\alpha]_{\mathrm{D}}^{20}=-14^{\circ}(c=1, \text { エタノ } \\
& \text { 一ル)，收素 } 26 \% \\
& \mathrm{R}=-\mathrm{CH}_{2}-\left\langle=\text { mp } 119 \sim 122^{\circ} \mathrm{G},[\alpha]_{\mathrm{D}}^{20}=+44^{\circ}(c=1 \text {, }\right. \\
& \text { エタノール)，収㵖 } 38 \%
\end{aligned}
$$

7) W. Robert, H. Haigh, J. Org. Chem., 27, 3375(1962).

8) R. K. Kulkarni, H. Morawetz, J. Polymer Sci., 54, 496(1961). 
$\mathrm{R}=-\mathrm{CH}_{2}\left\|_{\mathrm{H}}\right\|_{\mathrm{H}}$

0.4 , エタノール), 収染 $25 \%$

つぎにこれらのモノマーを架橋剂 $N, N^{\prime}$-ヘキサメチレンジメ タクリルアミドとともに酶酸エステル中，少量のアゾビスィソブ チロニトリルを加え共重合し，定星的に不溶性酸性樹脂を得た。

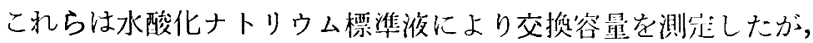
フェニルアラニン，バリン，トリプトフォン樹脂についておのお の $2.12,3.75,1.10 \mathrm{meq} / \mathrm{g}$ であった。一j $\beta$-フェネチルアル

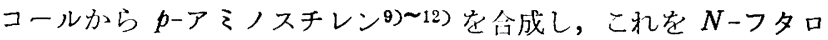
イルーLーアミノ酸クロリドとピリジン-無水エーテル中反応し, 定 量的につぎのモノマーを得た。

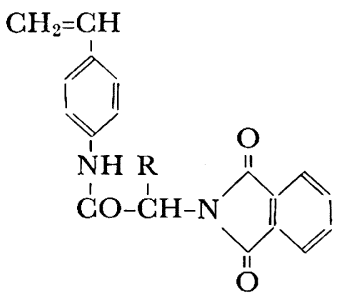

$\mathrm{R}=-\mathrm{CH}_{3}, \operatorname{mp} 183 \sim 185^{\circ} \mathrm{C},[\alpha]_{\mathrm{D}}=-66^{\circ}(c=1$, 酶酸工 ステル)

$\mathrm{R}=-\mathrm{CH}_{\mathrm{CH}_{3}}^{\mathrm{CH}_{3}}, \mathrm{mp} 173 \sim 175^{\circ} \mathrm{G},[\alpha]_{\mathrm{D}}^{20}=-34^{\circ}(c=1$, ク ロロホルム)

$\mathrm{R}=-\mathrm{CH}_{2}-\left\langle, \mathrm{mp} 230 \sim 232^{\circ} \mathrm{C},[\alpha]_{\mathrm{D}}^{20}=-100^{\circ}(c=1\right.$, クロロホルム)

これらのモノマーを無水ベンゼン中少量のアゾビスイソブチロ ニトリル存在下に架橋郕 $N, N^{\prime}$-ヘキサメチレンジアクリルアミ ドと共重合し，おのおの 65\% 収量で不溶な中性樹脂を得た。こ の際少量の未反応モノマーが残るが，その比旋光度は重合前と同 じであることからこの重合条件ではラセミ化は起こらないと考え られる。ついでこの樹脂をベンゼンで照濁し，ヒドラジンで処理 して脱フタロイル化を行ない，不溶性䘏基樹脂を得た。またそれ らの交換容量は塩酸標準液で測定し，バリン，フェニルアラニン

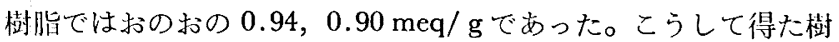
栺を乳バチで粉确し，約 200 メッシュの粒子にそろえ，これを充

9) “Organic Syntheses", 1, 30(1941).

10) H. Sobotka, Chem. Ber., 62, 2192(1929).

11) M. M. Koton, Yu. V. Mittin, F. S. Florinskir, Zhur., Obshchei. Khim., 25, 1469(1955); Chem. Abst., 50, 4323 $\mathrm{f}(1956)$.

12) J. H. Borer, H. Alul, J. Am. Chem. Soc., 81, 2136 (1959).
テン剂に用いてクロマトグラフィーを行ない，ラセる体の分割を 試みた。まず酸性樹脂のうちフェニルアラニン樹脂については樹 脂 $50 \mathrm{~g}$ を $2 \times 150 \mathrm{~cm}$ のカラムに $100 \mathrm{~cm}$ くらいに充テンし, 分 割を試みた。DL-マンデル酸については水を流出溶媒にし，先端 に $[\alpha]_{\mathrm{D}}^{20}=+9.8^{\circ}(c=0.2)$, 末端に $[\alpha]_{\mathrm{D}}^{20}=-3.9^{\circ}(c=0.2)$, 一方 DL-フェニルグリシンでは $0.5 \mathrm{~N}$ 塩酸水を流出溶媒とし, 先端に $[\alpha]_{\mathrm{D}}^{20}=+1.0(c=0.9)$ ，末端に $[\alpha]_{\mathrm{D}}^{20}=-1.6^{\circ}(c=0.67)$ とわずか に旋光度を認めた。つぎ塩基性樹脂についてはバリン，フェニ ルアラニン樹脂のおのおの $40 \mathrm{~g}$ を $2 \times 150 \mathrm{~cm}$ カラムに $70 \mathrm{~cm} く$ らいに充テンし，種々の濃度のアンモニア水を流出溶媒とし， DL-マンデル酸の分割を試みたが，低い濃度のものについて好結 果が得られた。0.003N アンモニア水を用いた場合，前者につい ては先端に $[\alpha]_{\mathrm{D}}^{20}=-40^{\circ}(c=0.02)$ ，末端に $[\alpha]_{\mathrm{D}}^{20}=+10^{\circ}(c=0.5)$, 後者では先端に $[\alpha]_{\mathrm{D}}^{20}=+2^{\circ}(c=1.4)$, 末端に $[\alpha]_{\mathrm{D}}^{20}=-1.3^{\circ}(c=$ 1.5)を示した。なお表 1 は塩基性バリン樹脂による DL-マンデル 酸の分割結果である。クロマトグラフィーはとくに圧力をかけず 自然流下させる。流下速度は約 $9 \mathrm{ml} / \mathrm{hr}$ である。溶出液はコレ クターによりそれぞれ $30 \mathrm{ml}$ ずつ 60 のフラクションに分取し, 各フラクションに含まれるマンデル酸の重量および旋光度は日立 EPS-2 型分光光度計, $\operatorname{Rex}$ 自動読み取り式旋光計を用いて測定 した。

表 1 DL-マンデル酸(500 mg)-0.003N フンモニア水

$\begin{array}{ccccc}\text { フラクション番号 } & c & \alpha & {[\alpha]_{\mathrm{D}}^{20}} & \text { 重量(mg) } \\ 1 & 0.02 & -0.008 & -40 & 0.4 \\ 2 & 0.07 & -0.036 & -5.1 & 14 \\ 3 & 1.20 & -0.049 & -4.0 & 24 \\ 4 & 0.60 & -0.032 & -5.3 & 12 \\ 5 & 0.60 & -0.021 & -3.5 & 12 \\ 6 & 0.60 & -0.006 & -1.0 & 12 \\ 7 & 0.60 & -0.004 & -0.7 & 12 \\ 8 & 0.60 & -0.004 & -0.7 & 12 \\ 9 & 0.60 & -0.002 & -0.3 & 12 \\ 10 \sim 49 & - & 0.000 & 0.0 & - \\ 50 & 0.70 & +0.011 & +1.6 & 14 \\ 51 & 0.70 & +0.013 & +1.9 & 14 \\ 52 & 0.70 & +0.020 & +2.9 & 14 \\ 53 & 0.70 & +0.031 & +4.4 & 14 \\ 54 & 0.70 & +0.064 & +9.1 & 14 \\ 55 & 0.50 & +0.050 & +10.0 & 10 \\ 55 \sim 60 & 0.50 & +0.050 & +10.0 & 10\end{array}$

本研究は文部省科学研究費の援助を受けて行なったものであ り，謝意を表します。

(1967 年 4 月, 日本化学会第 20 年会発表)

昭和 42 年 11 月 5 日 印 刷 昭和 42 年 11 月 10 日 発行 〔定価 300 円（送料 30 円）〕 発行萧編集人 東京都千代田区(神田局区内) 神田䥺河台 $1 丁$ 目 5 番地 印刷人東京都北区上 中里町 1 の 35 岩城広吉 倉 讯直 則 印刷所東京都北区上 中里町1 の 35 株式会社双文社

発 行 所東京都干他田区[神田局区内]神田駿河台 1 丁目 5 番地

社団日 本化学会振替眝金口座東京6058 番 (C) 1967 The Chemical Society of Japan 